\title{
Effects of Black Gram Flour (Vigna mungo L.) on the Proximate Composition, Texture \& Colour Profile and Microbiological Qualities of Duck Meat Patties
}

\author{
Kalpita Saikia $^{1 *}$, Saurabh Kumar Laskar ${ }^{1}$, Mineswar Hazarika ${ }^{1}$, Ankur Das ${ }^{1}$, \\ Abdul Saleque ${ }^{2}$ and Naba Nahar Deka ${ }^{2}$ \\ ${ }^{1}$ Department of Livestock Products Technology, College of Veterinary Science, Assam \\ Agricultural University, Khanapara, Guwahati-781022, Assam, India \\ ${ }^{2}$ Goat Research Station, Burnihat, Assam, India \\ *Corresponding author
}

\section{A B S T R A C T}

A study was conducted to evaluate the proximate composition, textural \& colour profile and microbiological quality of duck meat patties incorporated with different levels of Black Gram Flour (BGF). Three formulations were prepared with the incorporation of BGF at different levels: $5 \%\left(\mathrm{~T}_{1}\right), 10 \%\left(\mathrm{~T}_{2}\right)$, and $15 \%\left(\mathrm{~T}_{3}\right)$ and compared with the control $\left(\mathrm{C}_{\mathrm{T}}\right)$ sample prepared without $\mathrm{BGF}$. On the day of preparation, duck meat patties were evaluated in terms of proximate composition, texture and colour profile. The

Keywords

Duck meat, Black gram, Patties

Article Info

Accepted:

12 June 2019

Available Online:

10 July 2019 microbiological qualities were evaluated on the basis of total viable count (TVC), total viable psychrophilic count (TVPC) and coliform counts at 5 days interval up to 15 days under refrigerated storage $\left(6 \pm 1^{\circ} \mathrm{C}\right)$. The mean percent moisture, crude protein, ether extract revealed significantly $(\mathrm{P}<0.01)$ decreasing trend but the percent total ash revealed a non-significant $(\mathrm{P}>0.05)$ but slightly increasing trend. There were non-significant $(\mathrm{P}>$ 0.05) but slightly decreasing trend of calorie value with increasing levels of BGF in different patty formulations. The texture profile analysis (TPA) showed significant ( $\mathrm{P}<$ $0.05)$ increase in hardness and non-significant $(\mathrm{P}>0.05)$ increase of other texture qualities, whereas the fracturability and cohesiveness decreased non significantly $(P>0.05)$ with increased levels of BGF. Colour profile of the sample revealed non-significant $(\mathrm{P}>0.05)$ increased values of lightness $\left(\mathrm{L}^{*}\right)$, and decreased of redness $(a)$ and yellowness $(b)$ along with increased incorporation of BGF. Microbiologically duck patties with different formulations were found to be within the acceptable limit up to the $10^{\text {th }}$ days of refrigerated storage. The study revealed that duck meat patties with different formulation were found to be within acceptable limit in terms of proximate composition and microbiological quality upto 10 days.

\section{Introduction}

Meat is one of the most nutritious food items for non-vegetarian population, since it contains high quality protein, minerals, and vitamins with high bioavailability. With the advancement of research on food and nutrition, there is a growing awareness among 
the people about food qualities and their impact on health. This has resulted in the development of varieties of meat products to comply with the needs of consumers relating to the taste, health benefit and economy. Poultry is widely accepted as a source of economic and healthy meat all over the world. Among the various species of poultry, the rate of consumption of chicken is the highest. Preference towards duck meat was found to be less compared to chicken because of coarser texture and lower moisture content than chicken and also due to presence of inherent duck aroma (Huda et al., 2010). In India, the total poultry population is 729.2 million $\left(19^{\text {th }}\right.$ Livestock Census, 2012) of which fowl shares $95 \%$, duck $3 \%$ and turkey and others $2 \%$. Total duck population in the country is 23.5 million occupying the second position next to chicken in poultry meat sector $\left(19^{\text {th }}\right.$ Livestock Census, 2012). Though chicken constitutes majority of poultry meat in India, duck meat is slowly gaining popularity due to its high nutritional value (Kanagaraju et al., 2012). The protein content of duck meat is relatively lower than other poultry meat viz. chicken and turkey (Huda et al., 2011). On the other hand, compared to chicken and turkey, duck meat has higher lipid level and oxidative energy metabolism (Baeza, 2006). Duck meat and eggs are very popular in most of the South Asian countries and in Eastern and Southern part of India. With changing lifestyle the demand for duck meat products are increasing worldwide. The increasing demand for duck meat is potentially related to the fact that Asian restaurants became increasingly popular in Europe and North America in the recent years and they offer a wide variety of foods made from duck meat (Molnar S, 2017).

Despite the high popularity and availability of duck meat particularly in the North-East Region, studies on the use of duck meat in processed meat products are lacking behind. In order to musk the strong aroma of duck meat, development of duck meat products with different pulses and cereals or other are nonmeat ingredients may be helpful. Meat products to which pulses and pulse flours are added are a new trend in food science. The addition of pulse flours and fractions modifies the sensory appeal of meat products (Farooq et al., 2011). Black gram (Vigna mungo L.) or urad dal is one of the important pulse crops in India. Black gram supplies a major share of protein requirement of vegetarian population of the country (Kanade, 2006). Duck meat cooked with black gram is a much-preferred delicacy of the various ethnic groups of people of Assam and North-Eastern region.

Keeping in view of the above facts, the present study was carried out to evaluate the effects of incorporation of black gram flour (Vigna mungo L.) on the proximate composition, texture, colour profile and microbiological qualities of duck meat patties.

\section{Ethical approval}

Ethical approval was obtained from the Institutional Animal Ethics Committee, Faculty of Veterinary Science, AAU, Khanapara, Guwahati - 781022.

\section{Materials and Methods}

Local ducks were collected from the Goat Research Station, Burnihat and were scientifically slaughtered in the Department of Livestock Products Technology, College of Veterinary Science, AAU, Khanapara, Guwahati - 781022. After that Carcasses were stored at refrigeration temperature $\left(4 \pm 1^{\circ} \mathrm{C}\right)$ for overnight. On the following day, manual deboning was done and the lean and fat portion was separated as far as practicable. The required portion of meat was packed separately in food-grade polyethylene bags and then stored at $4 \pm 1{ }^{\circ} \mathrm{C}$ temperature for 24 hours. After 24 hours of storage, the deboned 
meat along with heart and gizzard were cut into small cubes of $3 \mathrm{~cm}$ size and then minced in a mechanical mincer through $4 \mathrm{~mm}$ plate. All the important curing ingredients viz. salt $(2 \%)$, sodium tri-polyphosphate $(0.3 \%)$ and sodium nitrite $(0.02 \%)$ were added to the minced meat and thoroughly mixed and stored at $4 \pm 1{ }^{\circ} \mathrm{C}$ for another 24 hours to facilitate proper curing. Black grams (Vigna mungo) were purchased from the nearby local supermarket and washed, dried and finally ground to flour in a mechanical grinder. The flour was hydrated and converted to paste $(1: 1 \mathrm{w} / \mathrm{w}$ hydration). Different proportions of hydrated black gram flour i.e. $0 \%, 5 \%, 10 \%$ and $15 \%$ along with other seasonings i.e. spices/condiments were added to the minced duck meat and mixed thoroughly to prepare the meat emulsion.

\section{Preparation of duck patties}

Duck Patties were prepared by using a specific size of moulder (height: $15 \mathrm{~mm}$ and diameter: $75 \mathrm{~mm}$ ) where $75 \mathrm{~g}$ of meat batter was placed in it. The moulded raw patties were then placed on a stainless steel tray pre-smeared with vegetable oil to prevent sticking.

Thereafter, tray with raw patties were placed in a preheated hot air oven at $185 \pm 5^{\circ} \mathrm{C}$ for cooking, until the internal temperature reached $75 \pm 2{ }^{\circ} \mathrm{C}$ which was recorded at the geometrical centre of the patties using a probe thermometer. Then the patties were turned upside down and cooked for another 5 min for proper cooking. The cooked patties were cooled to $35 \pm 5^{\circ} \mathrm{C}$ and patties were packed in LDPE pouches and stored under refrigeration for evaluation of different quality parameters.

\section{Proximate composition}

The proximate composition of duck meat patties in terms of percent moisture, crude protein, ether extract and total ash were determined on the day of preparation by following the standard procedure of Association of Official Analytical Chemist (AOAC, 1990).

\section{Calorie value}

By using the Atwater values i.e. for fat (9 $\mathrm{kcal} / \mathrm{g})$, protein $(4.02 \mathrm{kcal} / \mathrm{g})$ and carbohydrate $(4.00 \mathrm{kcal} / \mathrm{g})$ calorie values were calculated.

\section{Texture profile analysis}

The texture profile of the product in terms of hardness, fracturability, springiness, cohesiveness, chewiness and resilience were evaluated with a food texture analyser "(TAHD plus, Stable Micro Systems UK)" using the aluminium cylindrical probe (SMSP/36R). Patties sample of uniform size (approximately $2 \mathrm{~cm}$ cubes) were placed on the heavy duty platform and allowed for $50 \%$ compression. The samples were compressed twice during the test with the pre-test speed of $1 \mathrm{~mm} / \mathrm{s}$, test speed of $2.0 \mathrm{~mm} / \mathrm{s}$, and the posttest speed of $10.0 \mathrm{~mm} / \mathrm{s}$.

\section{Colour profile}

The colour $\left(\mathrm{L}^{*}, \mathrm{a}^{*}, \mathrm{~b}^{*}\right)$ of the product was evaluated with the help of a UV Visual Spectrophotometer (Cary 100biometer) using the solid sample holder.

\section{Microbiological quality}

Enumeration of the total viable count (TVC) and total viable psychrophilic count (TVPC) $(\log \mathrm{cfu} / \mathrm{g})$ of the patties sample was done at 5 days interval up to 15 days in standard plate count agar medium as described by (Harrigan and McCance, 1976) and incubated at $37^{\circ} \mathrm{C}$ and $6 \pm 1^{\circ} \mathrm{C}$ up to $24 \mathrm{~h}$ respectively. However, Coliform count was made in Brilliant green bile broth at similar incubation temperature (as in case of TVPC and TPC) upto 72hrs. 


\section{Statistical analysis}

The data obtained on studying different parameters were analysed statistically by employing the SAS, version 2 software. A total of five batches of patties with different formulations were prepared for the present study.

\section{Results and Discussion}

\section{Proximate composition}

As shown in table 1 , in terms of proximate composition, the moisture content was found to be highest in control sample. The moisture content showed a significant $(\mathrm{P}<0.01)$ decreasing trend from control to treated products which might be due to increase in the levels of hydrated black gram flour, contained less moisture than that of duck meat. Similar decreasing trend was recorded for moisture content in chicken seekh kabab due to addition of cow pea paste: 10, 15 and 20 percent levels by Bhat and Pathak (2012) and with increasing levels of hydrated wheat bran in spent hen nuggets by Rindhe et al., (2018)

The result for crude protein showed a $(\mathrm{P}<$ 0.01 ) decreasing trend from control to $T_{3}$ formulations and the possible reason of this declining trend in protein content might be due to the lower protein content of hydrated $(1: 1 \mathrm{w} / \mathrm{w})$ black gram flour than that of lean duck meat replaced in treated formulations. Khan (2014) observed similar finding with the incorporation of black bean paste at 10\%, 15\% and $20 \%$ levels in oven roasted chicken seekhkababs. The crude fat content of the duck meat patties decreased from control to treated formulations. Which might be due to the fact that duck meat contains considerable quantity of fat and in the patties, the duck meat were replaced by increasing levels of black gram flour in different treatment groups. Santhi and Kalaikannan (2014) also observed that crude protein and fat levels decreased significantly with the increased level of the oat flour in low-fat chicken nuggets. Bhat et al., (2011) also reported that the fat percentage decreased significantly with increase in the level of black bean in the treated formulations in ovenroasted chicken seekh kababs. Proteins are thought to be excellent fat binders in that they have dual functionality with respect to fat interaction and interfacial film formation (Anderson and Berry, 2011; Zayas, 1997).

A non-significant $(\mathrm{P}>0.05)$ but increasing trend of total ash content from control to treated formulations was observed in the duck meat patties. This might be attributed to higher mineral content in BGF than duck meat. Bhat et al., (2012) also reported a significantly higher value for total ash percentage at all extension levels of cowpea as compared to control in chicken seekh kababs. Rindhe et al., (2018) observed significant increase in total ash content of spent chicken meat balls with increasing levels of hydrated wheat bran.

The calorific value of the four different patty formulations revealed a non-significant $(\mathrm{P}>$ 0.05 ) but slightly decreasing trend from control to treated formulations. This might be due to progressively lowering of fat content and simultaneous increased in the levels of black gram flour. The carbohydrate content of increasing levels of black gram flour compensated for the decrease in percentage of fat resulted in smaller reduction in calorific values in the treated formulations than expected. Similar results were reported by in patties containing soybean hulls (Al Khalifa and Atia, 1997), by Rindhe et al., (2018) in spent hen nuggets with increasing levels of wheat bran.

\section{Texture profile}

Texture profile of duck meat patties showed a significant $(\mathrm{P}<0.05)$ increase in hardness 
value, whereas the fracturability and cohesiveness decreased non significantly $(\mathrm{P}>$ $0.05)$ also there were non-significant $(\mathrm{P}>$ $0.05)$ increase in springiness, gumminess, chewiness and resilience value along with increased incorporation of BGF in the treated products compared to control. Pietrasik (1999) observed no significant difference in cohesiveness due to use of different binders or additives. Huang et al., (2005) reported increase in the hardness value of pork meatballs due to the increased carbohydrate content. The hardness value of extended product was higher than control was reported by Malav et al., (2013) which might be due to gelling and biding nature of lentil flour in chicken meat blocks. Luckose and Pandey (2014) also observed that hardness was significantly influenced by the kind of nonmeat and binder used in meat batter.

An increase in the replacement level of legume flour led to a significant increase in the hardness, gumminess and chewiness of the treated products was observed by Motamedi et al., (2015) when compared to control in hamburger containing lentil and chickpea flour (Table 2-6).

Table.1 Formula for preparation of duck meat patties

\begin{tabular}{|l|c|c|c|c|}
\hline Ingredients & $\mathbf{C}_{\mathbf{T}}$ & $\mathbf{T}_{\mathbf{1}}$ & $\mathbf{T}_{\mathbf{2}}$ & $\mathbf{T}_{\mathbf{3}}$ \\
\hline Meat (prime and non-prime cut) & 67 & 62 & 57 & $\mathbf{5 2}$ \\
\hline Fat (skin + visceral organ) & 15 & 15 & 15 & $\mathbf{1 5}$ \\
\hline Black gram (1:1 w/w hydration) & 0 & 5 & 10 & $\mathbf{1 5}$ \\
\hline Spices & 3 & 3 & 3 & $\mathbf{3}$ \\
\hline Condiments & 5 & 5 & 5 & $\mathbf{5}$ \\
\hline Egg white & 1.65 & 1.65 & 1.65 & $\mathbf{1 . 6 5}$ \\
\hline Ice cubes & 5 & 5 & 5 & $\mathbf{5}$ \\
\hline Salt & 2 & 2 & 2 & $\mathbf{2}$ \\
\hline Sugar & 1 & 1 & 1 & $\mathbf{1}$ \\
\hline Baking soda & 0.03 & 0.03 & 0.03 & $\mathbf{0 . 0 3}$ \\
\hline Sodium nitrite & 0.02 & 0.02 & 0.02 & $\mathbf{0 . 0 2}$ \\
\hline Sodium tripolyphosphate & 0.3 & 0.3 & 0.3 & $\mathbf{0 . 3}$ \\
\hline Total & $\mathbf{1 0 0}$ & $\mathbf{1 0 0}$ & $\mathbf{1 0 0}$ & $\mathbf{1 0 0}$ \\
\hline
\end{tabular}

Table.2 Effect of different levels of black gram flour on the proximate composition of patties $($ Mean \pm SE)

\begin{tabular}{|l|c|c|c|c|}
\hline \multicolumn{1}{|c|}{ Treatment } & $\mathbf{C}_{\mathbf{T}}$ & $\mathbf{T}_{\mathbf{1}}(\mathbf{5 \%})$ & $\mathbf{T}_{\mathbf{2}}(\mathbf{1 0 \%})$ & $\mathbf{T}_{\mathbf{3}}(\mathbf{1 5 \%})$ \\
\hline Moisture (\%) & $58.08^{\mathrm{a}} \pm 1.05$ & $56.22^{\mathrm{ab}} \pm 0.78$ & $55.47^{\mathrm{b}} \pm 0.69$ & $54.77^{\mathrm{b}} \pm 0.47$ \\
\hline $\begin{array}{l}\text { Crude protein } \\
(\boldsymbol{\%})\end{array}$ & $23.89^{\mathrm{a}} \pm 0.41$ & $23.00^{\mathrm{ab}} \pm 0.43$ & $21.91^{\mathrm{bc}} \pm 0.34$ & $21.23^{\mathrm{c}} \pm 0.39$ \\
\hline Fat (\%) & $14.99^{\mathrm{a}} \pm 0.14$ & $13.50^{\mathrm{b}} \pm 0.12$ & $12.57^{\mathrm{c}} \pm 0.10$ & $11.83^{\mathrm{d}} \pm 0.18$ \\
\hline Ash (\%) & $1.78^{\mathrm{a}} \pm 0.21$ & $2.14^{\mathrm{a}} \pm 0.22$ & $2.25^{\mathrm{a}} \pm 0.20$ & $2.36^{\mathrm{a}} \pm 0.21$ \\
\hline $\begin{array}{l}\text { Calorie value } \\
(\mathbf{k} \text { cal/100g) }\end{array}$ & $237.17^{\mathrm{a}} \pm 3.24$ & $234.50^{\mathrm{a}} \pm 3.04$ & $232.18^{\mathrm{a}} \pm 2.83$ & $231.07^{\mathrm{a}} \pm 2.05$ \\
\hline
\end{tabular}

Means with dissimilar superscript (small letter) in a row differs significantly $(\mathrm{P}<0.01)$. 
Table.3 Effect of different levels of black gram flour on the texture profile of patties $($ Mean $\pm \mathrm{SE})$

\begin{tabular}{|l|l|l|l|l|l|l|}
\hline Treatment & Hardness $\left(\mathbf{N} / \mathbf{c m}^{2}\right)$ & $\begin{array}{l}\text { Fracturability } \\
(\mathbf{N})\end{array}$ & $\begin{array}{l}\text { Springiness } \\
(\mathbf{c m})\end{array}$ & $\begin{array}{l}\text { Cohesiveness } \\
(\mathbf{r a t i o})\end{array}$ & Chewiness (N/cm) & $\begin{array}{l}\text { Resilience } \\
(\mathbf{c m})\end{array}$ \\
\hline Control & $5667.54^{\mathrm{b}} \pm 469.68$ & $14.26^{\mathrm{a}} \pm 6.53$ & $0.178^{\mathrm{a}} \pm 0.01$ & $0.686^{\mathrm{a}} \pm 0.05$ & $698.55^{\mathrm{a}} \pm 272.07$ & $0.296^{\mathrm{a}} \pm 0.03$ \\
\hline $\mathbf{T}_{\mathbf{1}}$ & $6385.18^{\mathrm{b}} \pm 435.85$ & $10.35^{\mathrm{a}} \pm 6.11$ & $0.205^{\mathrm{a}} \pm 0.02$ & $0.669^{\mathrm{a}} \pm 0.04$ & $876.79^{\mathrm{a}} \pm 184.21$ & $0.355^{\mathrm{a}} \pm 0.06$ \\
\hline $\mathbf{T}_{\mathbf{2}}$ & $6510.43^{\mathrm{ab}} \pm 435.05$ & $9.66^{\mathrm{a}} \pm 0.93$ & $0.212^{\mathrm{a}} \pm 0.03$ & $0.609^{\mathrm{a}} \pm 0.09$ & $915.74^{\mathrm{a}} \pm 82.21$ & $0.391^{\mathrm{a}} \pm 0.05$ \\
\hline $\mathbf{T}_{\mathbf{3}}$ & $7911.96^{\mathrm{a}} \pm 633.21$ & $8.97^{\mathrm{a}} \pm 4.20$ & $0.217^{\mathrm{a}} \pm 0.04$ & $0.579^{\mathrm{a}} \pm 0.05$ & $1253.41^{\mathrm{a}} \pm 437.66$ & $0.414^{\mathrm{a}} \pm 0.04$ \\
\hline
\end{tabular}

Means with similar superscript (small letter) in a row did not differ significantly ( $\mathrm{P}>0.05)$.

Table.4 Effect of different levels of black gram flour on the colour profile of patties (Mean \pm SE)

\begin{tabular}{|c|c|c|c|}
\hline Treatment & L (lightness) & a (redness) & b (yellowness) \\
\hline $\mathbf{C}_{\mathbf{T}}$ & $1.950^{\mathrm{a}} \pm 0.012$ & $0.087^{\mathrm{a}} \pm 0.008$ & $0.833^{\mathrm{a}} \pm 0.002$ \\
\hline $\mathbf{T}_{\mathbf{1}}$ & $1.961^{\mathrm{a}} \pm 0.011$ & $0.081^{\mathrm{a}} \pm 0.003$ & $0.831^{\mathrm{a}} \pm 0.003$ \\
\hline $\mathbf{T}_{\mathbf{2}}$ & $1.965^{\mathrm{a}} \pm 0.013$ & $0.081^{\mathrm{a}} \pm 0.005$ & $0.827^{\mathrm{a}} \pm 0.001$ \\
\hline $\mathbf{T}_{\mathbf{3}}$ & $1.967^{\mathrm{a}} \pm 0.012$ & $0.069^{\mathrm{a}} \pm 0.008$ & $0.815^{\mathrm{a}} \pm 0.010$ \\
\hline
\end{tabular}

Means with similar superscript (small letter) in a row did not differ significantly $(\mathrm{P}>0.05)$.

Table.5 Effect of different levels of black gram flour on the total viable count (log cfu/g) of patties (Mean $\pm \mathrm{SE}$ )

\begin{tabular}{|c|c|c|c|c|}
\hline Treatment & $\mathbf{1}$ days & $\mathbf{5}$ days & 10 days & 15 days \\
\hline $\mathbf{C}_{\mathbf{T}}$ & ${ }^{\mathrm{D}} 2.26^{\mathrm{a}} \pm 0.05$ & ${ }^{\mathrm{C}} 3.72^{\mathrm{a}} \pm 0.01$ & ${ }^{\mathrm{B}} 4.81^{\mathrm{a}} \pm 0.01$ & ${ }^{\mathrm{A}} 5.86^{\mathrm{a}} \pm 0.02$ \\
\hline $\mathbf{T}_{\mathbf{1}}$ & ${ }^{\mathrm{D}} 2.09^{\mathrm{b}} \pm 0.05$ & ${ }^{\mathrm{C}} 3.56^{\mathrm{b}} \pm 0.03$ & ${ }^{\mathrm{B}} 4.70^{\mathrm{b}} \pm 0.03$ & ${ }^{\mathrm{A}} 5.77^{\mathrm{a}} \pm 0.04$ \\
\hline $\mathbf{T}_{\mathbf{2}}$ & ${ }^{\mathrm{D}} 1.94^{\mathrm{c}} \pm 0.02$ & $\mathrm{C}^{\mathrm{C}} 3.47^{\mathrm{bc}} \pm 0.05$ & ${ }^{\mathrm{B}} 4.67^{\mathrm{b}} \pm 0.04$ & ${ }^{\mathrm{A}} 5.75^{\mathrm{a}} \pm 0.04$ \\
\hline $\mathbf{T}_{\mathbf{3}}$ & ${ }^{\mathrm{D}} 1.72^{\mathrm{d}} \pm 0.03$ & ${ }^{\mathrm{C}} 3.35^{\mathrm{c}} \pm 0.07$ & ${ }^{\mathrm{B}} 4.64^{\mathrm{b}} \pm 0.05$ & ${ }^{\mathrm{A}} 5.72^{\mathrm{a}} \pm 0.03$ \\
\hline
\end{tabular}

Means with similar superscript (small letter) in row did not differ significantly $(\mathrm{P}>0.05)$

Mean with similar superscript (capital letter) did not differ significantly $(\mathrm{P}>0.05)$

Table.6 Effect of different levels of black gram flour on the total viable psychrophilic count (log $\mathrm{cfu} / \mathrm{g})$ of patties (Mean $\pm \mathrm{SE}$ )

\begin{tabular}{|c|c|c|c|c|}
\hline Treatment & 1 days & $\mathbf{5}$ days & $\mathbf{1 0}$ days & 15 days \\
\hline $\mathbf{C}_{\mathbf{T}}$ & - & ${ }^{\mathrm{C}} 1.99^{\mathrm{a}} \pm 0.03$ & ${ }^{\mathrm{B}} 2.48^{\mathrm{a}} \pm 0.04$ & ${ }^{\mathrm{A}} 3.37^{\mathrm{a}} \pm 0.07$ \\
\hline $\mathbf{T}_{\mathbf{1}}$ & - & ${ }^{\mathrm{C}} 1.83^{\mathrm{b}} \pm 0.05$ & ${ }^{\mathrm{B}} 2.43^{\mathrm{a}} \pm 0.04$ & ${ }^{\mathrm{A}} 3.29^{\mathrm{a}} \pm 0.06$ \\
\hline $\mathbf{T}_{\mathbf{2}}$ & - & $\mathrm{C}^{\mathrm{C}} 1.71^{\mathrm{bc}} \pm 0.03$ & ${ }^{\mathrm{B}} 2.39^{\mathrm{a}} \pm 0.05$ & $\mathrm{~A} 3.24^{\mathrm{a}} \pm 0.07$ \\
\hline $\mathbf{T}_{\mathbf{3}}$ & - & ${ }^{\mathrm{C}} 1.61^{\mathrm{c}} \pm 0.05$ & ${ }^{\mathrm{B}} 2.35^{\mathrm{a}} \pm 0.07$ & $\mathrm{~A} 3.21^{\mathrm{a}} \pm 0.07$ \\
\hline
\end{tabular}

Means with dissimilar superscript (small letter) in a row differ significantly $(\mathrm{P}<0.01)$

Mean with dissimilar superscript (capita letter) in a column differ significantly $(\mathrm{P}<0.01)$. 


\section{Colour profile}

The lightness $\left(\mathrm{L}^{*}\right)$ value showed a nonsignificant $(\mathrm{P}>0.05)$ increasing trend but redness $\left(\mathrm{a}^{*}\right)$ and yellowness $\left(\mathrm{b}^{*}\right)$ values decreased along with increased incorporation of black gram flour. The increased $\mathrm{L}^{*}$ value might be due to the light colour of BGF which diluted the dark colour of duck meat. Legume may cause myoglobin depletion and resulting higher ' $L^{*}$ ' value than rusk in low-fat meatballs as reported by Serdaroglu et al., (2005). Hale and Querry (1973) suggested that increase in surface water could decrease meat emulsion redness. The yellowness value showed a decreasing trend which might be due to lowering of fat by incorporation of black gram flour. Lorenzo et al., (2013) reported that the highest fat level produced an increased yellowness and a decreased in redness in dry cured duck Salchichon.

\section{Microbiological quality}

Non-significant $(\mathrm{P}>0.05)$ decrease in TVC of duck meat patties due to incorporation of black gram flour was found which might be possible reason to increase in levels of incorporation of $\mathrm{BGF}$ which reduced the lean and fat and at a time reduced the risk of microbial contamination, since meat and associated tissue are more prone to harbour bacteria. Similar result was reported by Saha $\mathrm{R}$ et al., (2014) in pork patties prepared with incorporation of wheat bran and oat bran. However, there was a significant $(\mathrm{P}<0.01)$ increase in the count of TVC both in control and treated products with increase in the storage period and this might be due to growth and multiplication of microorganisms, which was exposed to the product during its preparation, handling, packaging or subsequent storage. Similar findings were reported by Biswas et al., (2006) in duck sausages stored at ambient and refrigeration temperature, Biswas et al., (2011) in duck meat patties and Malav et al., (2014) in the study of shelf life evaluation of restructured chicken meat blocks extended with lentil flour.

A non-significant $(\mathrm{P}>0.05)$ but slight decrease in TVPBC in all the formulations of duck meat patties were observed, which might be due to the incorporation of BGF that reduced the lean and fat resulting in lower risk of microbial contamination, since meat and associated tissue are more prone to harbour bacteria. Similar result was reported by Jebin et al., (2012) in low-fat duck salami with incorporation of glutinous rice flour. No TVPBC was recorded on the $1^{\text {st }}$ day of storage, which might be due to cooking of patties at a higher temperature and the antimicrobial properties of ginger, garlic, salt and nitrates/nitrites incorporated in the preparation of duck patties. However, presence of organisms in the later days might be due to storage contamination and repeated handling of the finished product. There was a gradual increase in the count of viable psychrophilic microorganisms with the increase in the storage period. It might be due to growth and multiplication of psychrophilic organisms which come in contact with the product during handling, packaging and storage. Malav et al., (2014) reported that the result of psychrophilic count showed linear increasing trend from 0 to $15^{\text {th }}$ day of refrigeration storage in control as well as in treated chicken meat blocks with lentil flour. Biswas et al., (2011) reported that the TVPBC values increased significantly $(\mathrm{P}<0.01)$ with increase in storage period of duck patties at both ambient and refrigeration temperature. Similar result was reported by Biswas et al., (2006) on duck meat sausage, Kumar et al., (2015) in their studies on spent hen and duck nuggets.

The colititre values obtained in the study for both the control and treated formulation, 
besides, storing of the duck patties upto $15^{\text {th }}$ day of storage were found to be nil. The negative result, obtained in the present study might be due to better hygienic practices or might be due to destruction of the bacteria during cooking at higher temperature. Malav et al., (2014) in their studies reported that coliforms were not detected in control and treated products of chicken meat blocks extended with lentil flour during the storage period of $15^{\text {th }}$ days.

Based on the results of proximate composition, texture profile and microbiological quality, it can be concluded that duck meat patties of good nutritive value could be prepared with incorporation of black gram flour up to $15 \%$ level, substituting lean duck meat in formulation and the same desired values could be maintain up to 10 days at refrigeration temperature.

\section{References}

A.O.A.C. (1990). Official methods of Analysis of the Association of Official Analytical Chemist, $15^{\text {th }}$ Edn., USDA, Washington, D. C.

Al-Khalifa, A. and Atia, M. (1997). Effect of soy hull and fat on camel meat patties. Alexandria Sci. Exchange. 18: 303-311.

Anderson, E. T. and Berry, B. W. (2011). Effect of inner pea fiber on fat retention and cooking yield in high fat ground beef. International Journal of Food Research, 34: 689-694.

Baeza, E. (2006). Effects of genotype, age and nutrition on intramuscular lipids and meat quality. Proceedings of the Symposium COA/INRA Scientific Cooperation in Agriculture, Nov. 7-10, Tainan, pp: 7982.

Bhat, Z. F. and Pathak, V. (2011). Effect of black bean (Vigna mungo) on the quality characteristics of oven-roasted chicken seekh kababs. Journal of Stored Products and Postharvest Research. 2(1):15-23
Bhat, Z. F. and Pathak, V. (2012). Effect of cowpea (Vigna unguiculata) addition on the quality characteristics of oven roasted chicken shikh kababs. Asian Journal of Food and Agro Industry. 5(4): 331-344.

Biswas, S., Chakraborty, A., Patra, G. and Dhargupta, A. (2011). Quality and acceptability of duck Patties stored at ambient and refrigeration temperature. International Journal of Livestock Production. 1(1): 1-6.

Farooq, Z. and Boye J. I (2011). Novel food and industrial applications of pulse flours and Fractions. In: Tiwari B K, Gowen A, McKenna B, eds., Pulse Foods: Processing, Quality and Nutraceutical Applications. Academic Press London, UK.

Hale, G. M. and M. R. Querry. (1973). Optical constants of water in the $200 \mathrm{~nm}-200 \mathrm{um}$ wavelength region. Appl. Opt. 12: 555563.

Harrigan, W. E. and Mc Cancy, M. E. (1976). Laboratory Methods in Food and Dairy Microbiology. Adv. Press., London

Huang, S. C., Shiau, C. Y., Liu, T. E., Chu, C. L. and Hwang, D. F. (2005). Effect of rice bran on sensory and physicochemical properties of emulsified pork meatball. Journal of Meat Science, 70: 613-19.

Huda, N., Lin, O.J., Ping, Y.C. and Nurkhoeriyati, T. (2010) Effect of chicken and duck meat ratio on the properties of sausage. International Journal of Poultry Science. 9(6): 550-555.

Huda, N., Putra, A. A. and Ahmed, R. (2011). Potential application of duck meat for development of processed meat products. Current Research on Poultry Science. 1(1): 1-11.

Jebin, N., Laskar, S. K., Hazarika, M. and Nath, D. R. (2012). Effect of incorporation of glutinous rice flour on quality of duck meat salamis. Journal of Meat Science. 8(1-2): 76-79.

Kanade, R. S. (2006). Post-harvest profile of black gram (Report). Directorate of marketing and inspection, Dept. of 
Agriculture and Cooperation, Govt. of India. Pp. 1-6.

Kanagaraju, P. and Subramanian, A. (2012). Preparation of spent duck meat pickle and its storage studies at room temperature. American Journal of Food Technology. $1557-4571$.

Khan, A (2014). Impact of dark bean (Vigna mungo) on the quality characteristics of oven-roasted chicken seekh kababs. International Journal of Animal Science, Husbandry and Livestock Production ISSN: 2141-5191 Vol. 1 (1), pp. 020-028.

Kumar, R., Biswas, S., Singh, V. and Ram, M. (2014). Quality and shelf life evaluation of nuggets prepared from spent duck and spent hen meat. Explor. Anim. Med. Res. 5(2): 176-182.

Livestock census (2012). http://dahd.nic.in/sites/default/files/Livest ock\%20\%205.pdf

Luckose, F. and Pandey, M. C. (2014). Combined effect of non-meat proteins and different binders on low salt poultry meat system. International Journal of Advance Research. 2(11): 413-424.

Malav, O. P., Sharma, B. D., Talukdar, S., Mendiratta, S. K. and Kumar, R. R. (2013). Development of low-fat functional restructured chicken meat blocks extended with lentil flour. Indian Journal of Poultry Science. 48(3): 329332.

Malav, O. P., Sharma, B. D., Talukder, S., Gokulakrishnan, P. and Kumar, R. R. (2014). Shelf life evaluation of restructured chicken meat blocks extended with lentil flour at refrigerated storage $\left(4 \pm 1^{\circ} \mathrm{C}\right)$. Journal of Veterinary Public Health. 12(1).
Molnar S. (2017). Production and trade of duck products in global view. doi: 10.5604/01.3001.0010.3249

Motamedi, A., Vahdani, M., Baghaei, H. and Borghei, M. A. (2015). Considering the physicochemical and sensorial properties of momtaze hamburgers containing lentil and chickpea seed flour. Nutrition and Food Science Research. 2: 55-62.

Pietrasik, Z. (1999). Effect of content of protein, fat and modified starch on binding textural characteristics, and colour of comminuted scalded sausages. Journal of Meat Science. 51: 17-25.

Rindhe, S. N., Chatli, M. K., Wagh, R.V., Kumar, P., Malav O.P. and Mehta, N. (2018). Development and quality of fiber enriched functional spent hen nuggets incorporated with hydrated wheat bran. International Journal of Current Microbiology and Applied Science. 7(12): 3331-3345

Saha, R., Laskar, S. K., Nath, D. R., Hazarika, M. and Das, A. (2014). Enrichment effect of dietary fibre on certain quality attributes of fat reduced pork patties: Physico-chemical and microbiological qualities. Asian Journal of Dairy \& Food Research. 33(2): 119-122.

Santhi, D and Kalaikannan, A. (2014) The Effect of the Addition of Oat Flour in Low-Fat Chicken Nuggets. Journal of Nutrition \& Food Sciences. 4(1):1-4

Serdaroglu, M., Trup, G. Y. and Abrodimov, K. (2005). Quality of low-fat meatballs containing legume flour as extenders. Journal of Meat Science. 70: 99-105.

Zayas, J. F. (1997). Functionality of proteins in foods. New York: Springer

\section{How to cite this article:}

Kalpita Saikia, Saurabh Kumar Laskar, Mineswar Hazarika, Ankur Das, Abdul Saleque and Naba Nahar Deka. 2019. Effects of Black Gram Flour (Vigna mungo L.) on the Proximate Composition, Texture \& Colour Profile and Microbiological Qualities of Duck Meat Patties. Int.J.Curr.Microbiol.App.Sci. 8(07): 1399-1407. doi: https://doi.org/10.20546/ijcmas.2019.807.167 